\title{
KINETICS OF PHOSPHORUS UPTAKE AND ROOT MORPHOLOGY OF LOCAL AND IMPROVED VARIETIES OF MAIZE
}

\author{
Cynthia Torres de Toledo Machado; Ângela Maria Cangiani Furlani²* \\ ${ }^{1}$ Embrapa Cerrados, C.P. 08223, 73301-970 - Planaltina, DF - Brasil. \\ ${ }^{2}$ Instituto Agronômico, Centro de Pesquisa e Desenvolvimento de Solos e Recursos Ambientais/IAC, C.P. 28 - \\ 13001-970 - Campinas, SP - Brasil. \\ *Corresponding author 〈afurlani@iac.sp.gov.br>
}

\begin{abstract}
Interspecific and intraspecific differences in the efficiency of utilization of soil phosphorus (P) are explained, in part, by plant morphological and physiological variations, which characterize the plant for nutrient acquisition. As part of a study on maize genotypes characterization for P-uptake and use efficiency, kinetic parameters of $\mathrm{P}$ uptake and root morphological characters were evaluated for six local and improved maize varieties, grown in nutrient solution. The kinetic parameters related to $P$ influx were: maximal transport rate (Vmax), the Michaelis-Menten constant $(\mathrm{Km})$, and the external concentration when net uptake is zero (Cmin). Measured root morphological characters were: root length, radius, and surface area. Shoot and root dry matter yield and the P content in these parts were also determined. Diferences among varieties were observed in the kinetic parameters Vmax and $\mathrm{Km}$, root length and in root/shoot dry matter ratio. Lower Km values were better indicatives of $\mathrm{P}$ uptake ability of the varietes and were significantly correlated to higher dry matter production and P-efficiency index.

Key words: genetic variability, phopshorus acquisition, kinetics parameters, root system, nutritional efficiency
\end{abstract}

\section{CINÉTICA DE ABSORÇÃO DE FÓSFORO E MORFOLOGIA RADICULAR DE VARIEDADES LOCAIS E MELHORADAS DE MILHO}

\begin{abstract}
RESUMO: Diferenças inter e intraespecíficas na capacidade de utilizar o fósforo (P) do solo são explicadas, em parte, por variações na morfologia e fisiologia das raízes, as quais caracterizam as plantas quanto à aquisição do nutriente. Como parte de um estudo de caracterização de genótipos de milho quanto à eficiência na absorção e utilização de $\mathrm{P}$, avaliou-se a cinética de absorção e as características morfológicas do sistema radicular de seis variedades locais e melhoradas cultivadas em solução nutritiva. Foram determinados os parâmetros cinéticos de absorção de P: velocidade máxima (Vmax), a constante de Michaelis-Menten (Km) e a concentração mínima para a qual o influxo líquido é zero (Cmin); os parâmetros morfológicos da raiz: comprimento, raio e área do sistema radicular; e as variáveis de produção de matéria seca (MS) da parte aérea e raízes, da relação raiz/parte aérea, do conteúdo de $\mathrm{P}$ nessas partes e do índice de eficiência de utilização de P. Essas variáveis foram relacionadas às características cinéticas e morfológicas. As variedades diferiram quanto aos parâmetros Vmax, Km, comprimento de raízes e relação raiz/parte aérea. Os menores valores de $\mathrm{Km}$ e Cmin foram bons indicadores da capacidade de absorção de $\mathrm{P}$ das variedades, tendo se relacionado com as maiores produções de matéria seca e os maiores índices de eficiência de utilização de P.

Palavras-chave: variabilidade genética, aquisição de fósforo, parâmetros cinéticos, sistema radicular, eficiência nutricional
\end{abstract}

\section{INTRODUCTION}

Variations in root morphology and physiology have been shown to be correlated with genotypic differences in the plant utilization ability of soil available P. Root morphology refers to root length and radius, total root surface area, root surface area per unit of shoot and root hair density. Larger and ramified root systems with larger surface area and smaller root diameters are highly desirable for $\mathrm{P}$ acquisition, allowing plants to explore soil
$\mathrm{P}$ more effectively. The kinetics of $\mathrm{P}$ uptake and the plant ability of maintaining a normal metabolic level with lower $\mathrm{P}$ tissue concentrations, guaranteeing satisfactory dry matter or grain yields, are physiological mechanisms that plant deals with to achieve higher P utilization efficiency. The allosteric control of the aerial plant part demand for nutrients involves also the modulation of the kinetic parameters of root uptake (Marschner, 1995).

Variations among genotypes for root morphological characters and $\mathrm{P}$ uptake kinetic parameters derive from 
the conditioning environment action, mainly soil factors. Such variability in maize genotypes, and in other plant species, has been considered as a plant adaptation alternative to the higher or lower soil $\mathrm{P}$ availability, since this nutrient moves from soil to root surface by diffusion, a process which depends strongly on physical and chemical soil atributes (Nielsen \& Barber, 1978; Baligar \& Barber, 1979; Schenk \& Barber, 1979a, 1979b; 1980; Anghinoni et al., 1989; Alves et al., 1998; Ciarelli et al., 1998).

The active uptake of nutrients by plants follows the saturation kinetics of Michaelis-Menten, described by the parameters Vmax, $\mathrm{Km}$ and $\mathrm{Cmin}$, the same that define enzime activity. The maximal uptake rate or influx (Vmax or Imax) is obtained when all the available carrier sites are loaded, that is, the maximal transport rate. During the uptake process of a certain nutrient, only the net uptake of ions is determined, resultant of the inflow and outflow of ions at root surface.

$\mathrm{Km}$ is the Michaelis-Menten constant, equal to the substrate ion concentration that gives half of the maximal transport rate; the lower this constant, the higher the affinity between the carrier sites and ions. Cmin is the concentration at which net uptake of ions ceases before the solution is completely depleted of ions; it is the lowest concentration at which roots can extract ions from the soil solution (Marschner, 1995). Cmin concentrations differ considerably among plant species.

Roots are able to alter the uptake kinetics in response to low P availability by increasing Vmax (Nielsen \& Barber, 1978; Schenk \& Barber, 1980; Jungk et al., 1990; Alves et al., 1998). However, studies with wild species showed that a lower $\mathrm{P}$ uptake rate might be a characteristic of plant adaptation to infertile soils, since P diffusion from the soil to root surface would be the main restriction in such environment (Chapin III, 1983). Working with contrasting rice inbred lines for P efficiency, Furlani (1988) found lower values of Vmax and Km for a P-efficient genotype during a kinetics trial under low available $\mathrm{P}$ concentration. In sorghum, P-efficient inbred lines under low P developed larger root systems, lower P uptake rates and transported more $\mathrm{P}$ from older to younger leaves (Furlani et al., 1984). In maize, Ciarelli et al. (1998) observed inverse relation between P-uptake rate and length of root system among single and double hybrids, and among inbred lines and their progenies.

Differences in root morphology and physiology among maize genotypes were related to different $\mathrm{P}$ accumulation by plants in nutrient solution and/or soil. Genotypes with larger and longer root systems presented also higher dry matter yield of shoot and root (Warncke \& Barber, 1974; Schenk \& Barber, 1979a, 1979b; Baligar \& Barber, 1979; Furlani et al., 1984; Furlani, 1988). Significant differences in root surface area of field grown maize genotypes were positively correlated with shoot and root dry matter yield at flowering stage (Schenk \&
Barber, 1980). Similar correlation between root length and dry matter yield of shoot and root was also observed among maize inbred lines and their $\mathrm{F}_{1}$ hybrids grown in nutrient solution (Furlani et al., 1984; Ciarelli et al., 1998). These results are evidences of the effect of root morphology and P-uptake kinetic characteristics on shoot and root growth and on dry matter yield of plants, grown either in soil or nutrient solution, and that such parameters are inheritable characters, passive of being selected and improved through a plant breeding program.

Machado et al. (1999; 2001) evaluated local and improved maize varieties under low external $\mathrm{P}$ concentration and observed differences among them in relation to grain, shoot and root dry matter yield, and P-concentration and accumulation in plant parts. As a subsequent study, the present research determined the kinetics of $P$ uptake and root morphological characters for six local and improved maize varieties, contrasting by yield and $\mathrm{P}$ accumulation characteristics.

\section{MATERIAL AND METHODS}

The experiment was carried out in a greenhouse and a growth chamber, in Campinas, SP, Brazil, during 1997, using young plants grown in nutrient solution. The experimental design consisted of randomized complete blocks with five replications. Six contrasting maize varieties for the P-efficiency characters were used, according to the criteria proposed in previous studies (Machado, 2000; Machado et al., 2001): three local varieties - 'Caiano de Sobrália', 'Carioca' and 'Catetão' - and three improved varieties - 'Nitrodente', 'Sol da Manhã NF' and 'BR 106'.

Seeds were germinated between moist paper towels, and seven-day-old, uniform-sized seedlings were transferred to 3.0 L plastic pots, provided with lids, containing nutrient solution. Three seedlings of each variety were left per pot, suspended in the nutrient solution. The nutrient solution used for plant growth had the following composition, according to Furlani \& Furlani (1988), using p.a. reagents and deionized water $\left(\mathrm{mg} \mathrm{L}^{-1}\right): \mathrm{Ca}=$ $151 ; \mathrm{K}=141 ; \mathrm{Mg}=17 ; \mathrm{N}-\mathrm{NO}_{3}=138 ; \mathrm{N}^{-\mathrm{NH}_{4}}=20 ; \mathrm{S}=$ $56 ; \mathrm{Cl}=33 ; \mathrm{Fe}=3.6 ; \mathrm{Mn}=0.5 ; \mathrm{B}=0.27 ; \mathrm{Zn}=0.15$; $\mathrm{Cu}=0.04 ; \mathrm{Mo}=0.08$, as $\mathrm{Ca}\left(\mathrm{NO}_{3}\right)_{2} \cdot 4 \mathrm{H}_{2} \mathrm{O} ; \mathrm{NH}_{4} \mathrm{NO}_{3} ; \mathrm{KCl}$; $\mathrm{K}_{2} \mathrm{SO}_{4} ; \mathrm{KNO}_{3} ; \mathrm{MgSO}_{4} \cdot 7 \mathrm{H}_{2} \mathrm{O}$, respectively; Fe-EDTA was prepared with HEDTA and $\mathrm{FeSO}_{4} \cdot 7 \mathrm{H}_{2} \mathrm{O} ; \mathrm{MnCl}_{2} \cdot 4 \mathrm{H}_{2} \mathrm{O}$; $\mathrm{H}_{3} \mathrm{BO}_{3} ; \mathrm{ZnSO}_{4} \cdot 7 \mathrm{H}_{2} \mathrm{O} ; \mathrm{CuSO}_{4} \cdot 5 \mathrm{H}_{2} \mathrm{O}$ and $\mathrm{Na}_{2} \mathrm{MoO}_{4} \cdot 2 \mathrm{H}_{2} \mathrm{O}$. Phosphorus was added at $4 \mathrm{mg} \mathrm{L}^{-1}\left(0.13 \mathrm{mmol} \mathrm{L}^{-1}\right)$, as $\mathrm{KH}_{2} \mathrm{PO}_{4}$, and this level has been defined as the adequate $\mathrm{P}$-stress pressure to differentiate maize genotypes in relation to $\mathrm{P}$ efficiency, based on previous experiments with several P-concentrations (Furlani et al., 1984; Ciarelli et al., 1998; Machado, 2000; Machado et al., 2001). Nutrient solutions were constantly aerated, and the initial solution $\mathrm{pH}$ was 5.2, which was monitored during plant growth each other day. 
Plants were grown in these nutrient solutions up to 24 days of age and only deionized water was frequently added to the pots, readjusting the initial volume, according to the technique proposed for the evaluation of a relatively high number of young plants under P-stress (Furlani et al., 1984; Furlani \& Furlani, 1988). The conditions in the greenhouse during plant growth were: maximum day temperature $=36 \pm 6{ }^{\circ} \mathrm{C}$; and minimum night temperature $=24 \pm 1^{\circ} \mathrm{C}$.

When plants were 24-day-old, before running the kinetics experiment, an addicional trial was carried out with the objective of defining the adequate $\mathrm{P}$ concentration for $\mathrm{P}$ depletion to occur within 24 hours. Three $\mathrm{P}$ concentrations $\left(4,8\right.$ and $12 \mathrm{mg} \mathrm{L}^{-1}$ or $0.13,0.26$ and 0.40 mmol L ${ }^{-1}$ ), two contrasting maize varieties ('BR 106' and 'Catetão'), previously evaluated and selected (Machado, 2000; Machado et al., 2001) and three replications were used in this test. The $\mathrm{P}$ concentration defined for the short term kinetics experiment was $8 \mathrm{mg} \mathrm{L}^{-1}$ or $0.26 \mathrm{mmol} \mathrm{L}^{-1}$. Considering that maize plants at this age already present relatively extensive root systems and were grown under $\mathrm{P}$-stress pressure, $\mathrm{P}$ was fastly depleted from solution in less than 24 hours.

\section{Determination of $P$ uptake kinetic parameters and root morphological characters}

The 24-day-old plants were transferred to other 3.0-L containers with fresh nutrient solutions of the same composition, but without phosphorus, in a growth chamber with controlled light and temperature $\left(200 \mu \mathrm{mol} \mathrm{m}{ }^{-2}\right.$ $\mathrm{s}^{-1}$; temperature $=30 \pm 1{ }^{\circ} \mathrm{C}$; and relative humidity $=55 \%$ ). Plants remained 24 hours in the P-free nutrient solution, after what they were suspended from solution, so that $\mathrm{P}$ was added to the pots at the concentration of $8 \mathrm{mg} \mathrm{P} \mathrm{L}^{-1}$ (or $0.26 \mathrm{mmol} \mathrm{P} \mathrm{L}^{-1}$ ). Solutions were carefully agitated and a $10 \mathrm{~mL}$ aliquot sample was taken from each pot for the initial $\mathrm{P}$ concentration determination. Plants were put into nutrient solutions and $\mathrm{P}$ depletion from solutions was followed by taking $10 \mathrm{~mL}$ aliquot samples from each pot at 90 minute intervals. The solution level in each pot was readjusted to its initial volume with deionized water before each sample was taken. During 10 hours and 30 minutes seven samples were taken at 90 minute intervals, and a last one 24 hours after the beginning of the test. The aliquot samples were stored in small, capped glass vials under refrigeration, until $\mathrm{P}$ analyses were performed colorimetrically, according the method of Murphy \& Riley (1962).

Plants were rinsed in distilled water and separated into shoot and root. Samples of fresh roots were taken for the determination of root length and surface area, using the software 'SIARCS' developed by EMBRAPACNPDIA (Jorge, 1996). The average root radius was estimated as described by Rossiello et al. (1995). Shoot and root were dried in a forced air oven at $70^{\circ} \mathrm{C}$, for dry mat- ter determination, and after that, ground in a Wiley-type grinder and analysed for $\mathrm{P}$ using the ammonium vanadomolybdate method described in Bataglia et al. (1983). The P-efficiency index (EI) proposed by Siddiqi \& Glass (1981), evaluates the quantity of dry matter (DM) produced per unit of $\mathrm{P}$ concentration in the tissue and was calculated according to: $\mathrm{EI}=(\mathrm{DM})^{2} /$ total $\mathrm{P}$ content.

Kinetic parameters were estimated using the software 'Cinetica' proposed by Ruiz (1985), which plots the quantity of $\mathrm{P}$ in the solution $(\mathrm{Q})$ against time ( $\mathrm{t}$ ) and grafically represents two equations: the first, a linear regression and the second, a potential or exponential regression, chosing the one that best fits the data. Vmax is calculated from the linear equation, and $\mathrm{Km}$ from both equations (Ruiz, 1985). Cmin was estimated from the equation adjusted to the data for the last interval of $\mathrm{P}$ depletion from solution. The values for Vmax, $\mathrm{Km}$ and $\mathrm{Cmin}$ were calculated for each replication and submitted to analyses of variance, comparison of means using the Duncan $(P=0.05)$ and simple correlation tests.

\section{RESULTS AND DISCUSSION}

Differences among varieties were observed for the maximal P uptake rate (Vmax), Michaelis-Menten constant $(\mathrm{Km})$ and root length (Table 1). 'Sol da Manhã NF' and 'BR 106' presented the highest and lowest $V \max$, respectively, the other varieties having intermediate values, not different from each other. Values obtained for the Vmax of the maize varieties were very close to those observed by Ciarelli et al. (1998) for maize hybrids grown in nutrient solution under similar conditions and $\mathrm{P}$ concentration. 'BR 106' presented the lowest value for the constant $\mathrm{Km}$, followed by 'Nitrodente' and 'Caiano' (Table 1).

The group of improved varieties had lower average $\mathrm{Km}\left(29.38 \mu \mathrm{mol} \mathrm{L^{-1 }}\right)$ as compared to the group of local varieties $\left(37.92 \mu \mathrm{mol} \mathrm{L}^{-1}\right)$. No significant contrast was observed among local and improved varieties for Vmax and $\mathrm{Km}$ parameters. Variations within groups were only observed for the improved varieties, as evidenced by the contrasting behaviour of 'Sol da Manhã NF' and 'BR 106' (Table 1). Results obtained for the minimal concentration (Cmin) did not differ among varieties, probably because of the large variation observed among replicates, resulting in a high coefficient of variation (Table 1).

Considering the root morphological characters, plants differed significantly only for root length. 'Nitrodente' had the longest root system as compared to the local 'Carioca' and to the improved 'Sol da Manhã NF', which had the shortest root systems. The improved varieties presented, in average, longer root systems (139 $\mathrm{m})$ than the local varieties $(127 \mathrm{~m})$. No differences were found between the improved and local groups of varieties for root surface area and average root radius. Within 
groups, variation in root surface area was only observed for the improved varieties, pointing out 'Nitrodente' with the largest and 'Sol da Manhã NF' with the smallest values (Table 1).

Results related to dry matter yield, $\mathrm{P}$ accumulation and $\mathrm{P}$ utilization efficiency are presented in Table 2. Differences among varieties were observed for dry matter yield, dry matter partition and $\mathrm{P}$ utilization efficiency index (EI). 'BR 106' and 'Sol da Manhã NF' presented the highest and lowest shoot and root dry matter yield, respectively. Local and improved varieties produced similar quantities of shoot and root dry matter. No significant differences were observed between these groups for plant parts or total dry matter yield and root to shoot ratio. Differences within the groups were observed only for the improved varieties, evidenced by the 'BR 106' and 'Sol da Manhã NF', contrasting varieties for dry matter yield and shoot/root dry matter partition (Table 2). These observation confirmed previous results obtained by Machado et al. (2001) with the same varieties.

The root to shoot dry matter ratio is one of the characters used to describe the morphology of root systems (Schenk \& Barber, 1979a; 1979b). High root/shoot dry matter ratios have been related to a higher susceptibility of the plant to P deficiency. Higher values for root/ shoot dry matter ratios have been observed in several genotypes of diferent plant species grown under P-stress conditions, in comparison to those obtained under regular P supply (Föhse et al., 1988; Gill et al., 1992; Fageria \& Baligar, 1989). Similar results were obtained with maize varieties used in the present and previous studies
(Machado, 1995; Machado et al., 2001), and may be attributed to plant growth inhibition under $\mathrm{P}$ deficiency conditions that occurs firstly on the aerial part, resulting in an initial relative higher root growth. This plant perfomance may also be attributed to different phenotypic responses to the lower external $\mathrm{P}$ availability, being a plant adaptation expression which may provide a higher efficiency of P uptake (Föhse et al., 1988). The higher root/shoot ratios for dry matter yield observed in 'BR 106', 'Caiano' and 'Nitrodente' were also related to large shoots and roots, not meaning that these varieties were more susceptible to $\mathrm{P}$ deficiency than the others (Table 2 ). No differences among varieties were observed for $P$ contents in shoot, root and whole plant, as well as for the $\mathrm{P}$ distribution in plant parts, indicating that plants were very similar in relation to their nutritional status under the conditions of this experiment (Table 2).

Differences among varieties were observed for the utilization of the efficiency index (E.I.), whose variation followed the dry matter yield variation. Varieties with higher yield - 'BR 106', 'Nitrodente' and 'Caiano' - presented also higher ability to use the P absorbed, and 'Sol da Manhã NF' had the lowest E.I. (Table 2). These results confirmed those obtained with 'Nitrodente' and 'BR 106', when plants were grown in nutrient solution with increasing $\mathrm{P}$ concentrations and presented higher E.I. values in comparison to other varieties (Machado et al., 2001). No differences were found between groups for the E.I.values, evidencing that local and improved varieties had similar efficiency for P utilization. Within groups, no differences were observed among local varieties; among

Table 1 - Kinetic parameters ${ }^{(1)}$ of $\mathrm{P}$ uptake and root morphological characters of maize varieties grown up to 24 days of age in nutrient solution (pots with three plants; average of five replications).

\begin{tabular}{|c|c|c|c|c|c|c|}
\hline Variety & $V \max$ & $\mathrm{Km}$ & $\mathrm{Cmin}$ & Root surface area & Root length & Root radius \\
\hline & $\mu \mathrm{mol} \mathrm{g}{ }^{-1} \mathrm{~h}^{-1}$ & - & 1 -....... & $\mathrm{cm}^{2}$ & $\mathrm{~m}$ & $\mathrm{~mm}$ \\
\hline Caiano & $41.93 \mathrm{bc}$ & $33.66 \mathrm{ab}$ & 6.02 & 831 & $133 \mathrm{abc}$ & 0.10 \\
\hline Carioca & $50.48 \mathrm{ab}$ & $38.64 \mathrm{a}$ & 2.26 & 715 & $117 \mathrm{bc}$ & 0.10 \\
\hline Catetão & $47.47 \mathrm{abc}$ & $41.47 \mathrm{a}$ & 2.14 & 805 & $132 \mathrm{abc}$ & 0.10 \\
\hline Sol da Manhã NF & $56.55 \mathrm{a}$ & $40.77 \mathrm{a}$ & 2.47 & 681 & $106 \mathrm{c}$ & 0.10 \\
\hline Nitrodente & $39.82 \mathrm{bc}$ & $26.88 \mathrm{ab}$ & 1.97 & 978 & $160 \mathrm{a}$ & 0.10 \\
\hline BR 106 & $37.40 \mathrm{c}$ & $20.49 \mathrm{~b}$ & 1.52 & 900 & $151 \mathrm{ab}$ & 0.10 \\
\hline \multicolumn{7}{|l|}{ Analysis of variance } \\
\hline $\mathrm{FV}{ }^{(2)}$ & $4.06 *$ & $2.77 *$ & $1.09 \mathrm{~ns}$ & $1.99 \mathrm{~ns}$ & $2.86^{*}$ & $1.37 \mathrm{~ns}$ \\
\hline Flv ${ }^{(2)}$ & $1.46 \mathrm{~ns}$ & $0.61 \mathrm{~ns}$ & $1.96 \mathrm{~ns}$ & $0.59 \mathrm{~ns}$ & $0.01 \mathrm{~ns}$ & $1.00 \mathrm{~ns}$ \\
\hline Fiv $^{(2)}$ & $8.45 * *$ & $4.19 *$ & $0.09 \mathrm{~ns}$ & $3.80 *$ & $0.06 \mathrm{~ns}$ & $1.00 \mathrm{~ns}$ \\
\hline $\mathrm{Fg}^{(2)}$ & $0.48 \mathrm{~ns}$ & $4.27 *$ & $1.34 \mathrm{~ns}$ & $1.18 \mathrm{~ns}$ & $14.19 * *$ & $1.00 \mathrm{~ns}$ \\
\hline $\mathrm{CV}(\%)^{(3)}$ & 17.59 & 33.66 & 128.93 & 21.56 & 19.83 & 4.92 \\
\hline
\end{tabular}

Means followed by common letters are not different by Duncan's test $(P=0.05)$.

${ }^{(1)} \mathrm{Vmax}=$ maximal $\mathrm{P}$ uptake rate (per unit of root dry matter); Km = Michaelis-Menten constant; Cmin = minimal external concentration.

${ }^{(2)} \mathrm{Fv}=\mathrm{F}$ test for varieties; Flv $=\mathrm{F}$ test for local varieties; Fiv $=\mathrm{F}$ test for improved varieties; Fg $=\mathrm{F}$ test for variety groups; ; ** Statistical significance at $P=0.01 ; *$ Statistical significance at $P=0.05 ; \mathrm{ns}=$ statistically not significant.

${ }^{(3)} \mathrm{CV}=$ Coefficient of variation. 
Table 2 - Dry matter yield and root/shoot ratio of dry matter (R/S); plant part and total P content, and shoot/root ratio of Pcontent (S/R); and P-utilization efficiency index of maize varieties grown up to 24 days of age in nutrient solution (pots with three plants; average of five replications).

\begin{tabular}{|c|c|c|c|c|c|c|c|c|c|}
\hline \multirow[b]{2}{*}{ Variety } & \multicolumn{4}{|c|}{ Dry matter (DM) } & \multicolumn{4}{|c|}{ P-content } & \multirow[b]{2}{*}{ P-UEI ${ }^{(1)}$} \\
\hline & Shoot & Root & Whole plant & $\mathrm{R} / \mathrm{S}$ & Shoot & Root & Whole plant & $\mathrm{S} / \mathrm{R}$ & \\
\hline & \multicolumn{3}{|c|}{ - } & & \multicolumn{3}{|c|}{ - } & & $\mathrm{g}^{2} \mathrm{DM} \mathrm{mg}^{-1} \mathrm{P}$ \\
\hline Caiano & $4.22 \mathrm{ab}$ & $1.64 \mathrm{ab}$ & $5.86 \mathrm{ab}$ & $0.39 \mathrm{ab}$ & 18.34 & 1.24 & 19.58 & 18.09 & $1.81 \mathrm{ab}$ \\
\hline Carioca & $4.07 \mathrm{~b}$ & $1.35 \mathrm{bc}$ & $5.42 \mathrm{~b}$ & $0.33 \mathrm{c}$ & 19.40 & 0.87 & 20.27 & 24.50 & $1.47 \mathrm{bc}$ \\
\hline Catetão & $4.20 \mathrm{ab}$ & $1.47 \mathrm{~b}$ & $5.67 \mathrm{~b}$ & $0.35 \mathrm{bc}$ & 19.83 & 0.80 & 20.63 & 25.06 & $1.59 \mathrm{~b}$ \\
\hline Sol da Manhã NF & $3.39 \mathrm{c}$ & $1.10 \mathrm{c}$ & $4.49 \mathrm{c}$ & $0.32 \mathrm{c}$ & 18.81 & 0.90 & 19.72 & 22.12 & $1.03 \mathrm{c}$ \\
\hline Nitrodente & $4.43 \mathrm{ab}$ & $1.63 \mathrm{ab}$ & $6.06 \mathrm{ab}$ & $0.37 \mathrm{abc}$ & 18.78 & 0.93 & 19.71 & 20.51 & $1.90 \mathrm{ab}$ \\
\hline BR 106 & $4.63 \mathrm{a}$ & $1.87 \mathrm{a}$ & $6.50 \mathrm{a}$ & $0.40 \mathrm{a}$ & 19.02 & 1.03 & 20.05 & 18.97 & $2.14 \mathrm{a}$ \\
\hline \multicolumn{10}{|l|}{ Analysis of variance } \\
\hline $\mathrm{FV}{ }^{(2)}$ & $6.83 * *$ & $6.62 * *$ & $7.50 * *$ & $3.40 *$ & $0.36 \mathrm{~ns}$ & $1.35 \mathrm{~ns}$ & $0.22 \mathrm{~ns}$ & $1.40 \mathrm{~ns}$ & $5.37 * *$ \\
\hline $\mathrm{Flv}^{(2)}$ & $0.25 \mathrm{~ns}$ & $2.06 \mathrm{~ns}$ & $0.79 \mathrm{~ns}$ & $3.67 *$ & $0.78 \mathrm{~ns}$ & $3.12 \mathrm{~ns}$ & $0.38 \mathrm{~ns}$ & $2.56 \mathrm{~ns}$ & $1.10 \mathrm{~ns}$ \\
\hline $\mathrm{Fiv}^{(2)}$ & $16.83 * *$ & $14.50 * *$ & $17.94 * *$ & $8.00 * *$ & $0.02 \mathrm{~ns}$ & $0.23 \mathrm{~ns}$ & $0.05 \mathrm{~ns}$ & $0.42 \mathrm{~ns}$ & $12.17 * *$ \\
\hline $\mathrm{Fg}{ }^{(2)}$ & $0.002 \mathrm{~ns}$ & $0.29 \mathrm{~ns}$ & $0.03 \mathrm{~ns}$ & $0.26 \mathrm{~ns}$ & $0.001 \mathrm{~ns}$ & $0.01 \mathrm{~ns}$ & $0.22 \mathrm{~ns}$ & $1.05 \mathrm{~ns}$ & $0.26 \mathrm{~ns}$ \\
\hline $\mathrm{CV}(\%)^{(3)}$ & 8.78 & 15.32 & 9.85 & 10.30 & 10.24 & 31.15 & 9.65 & 25.12 & 22.57 \\
\hline
\end{tabular}

Means followed by common letters are not different by Duncan's test $(P=0.05)$.

${ }^{(1)} \mathrm{P}-\mathrm{UEI}=$ phosphorus utilization efficiency index $=(\text { unity of dry matter })^{2} / \mathrm{unit} \mathrm{P}$ absorbed.

${ }^{(2)} \mathrm{Fv}=\mathrm{F}$ test for varieties; Flv $=\mathrm{F}$ test for local varieties; Fiv $=\mathrm{F}$ test for improved varieties; Fg = F test for variety groups; ** Statistical significance at $P=0.01 ; *$ Statistical significance at $P=0.05 ; \mathrm{ns}=$ statistically not significant.

${ }^{(3)} \mathrm{CV}=$ Coefficient of variation.

the improved varieties, 'BR 106' differed significantly from 'Sol da Manhã NF' (Table 2).

Table 3 presents the correlation coeficients between the kinetic parameters (Vmax, Km and Cmin) and other evaluated characteristics. 'BR 106' had a negative correlation between Vmax and Km, evidencing ability of adaptation of its $\mathrm{P}$ uptake kinetics to the external available P. Schenk \& Barber (1979b) observed positive correlations among Vmax, $\mathrm{Km}$ and $\mathrm{Cmin}$ for five maize genotypes which presented variability for root morphological and physiological characters. In this case, genotypes presented high Vmax, $\mathrm{Km}$ and Cmin combinations and were superior under high $\mathrm{P}$ conditions, or presented low values for $\mathrm{Vmax}, \mathrm{Km}$ and $\mathrm{Cmin}$ and were superior under low P conditions. None of the genotypes exhibited combinations of high and low values for the kinetic parameters. 'Carioca' and 'Sol da Manhã NF' presented positive correlations between $\mathrm{Km}$ and $\mathrm{Cmin}$, indicating that these varieties presented high values for Km (low affinity of the carrier sites for $\mathrm{Pi}$ ) associated to high values for Cmin (minimal concentrations) (Table 3). Some varieties showed also negative correlation between $\mathrm{Km}$ and dry matter yields of shoot, root, whole plant, and E.I. (Table 3).

'Sol da Manhã NF' presented positive correlations between surface area, root length and dry matter yield and efficiency index (E.I.). The variety Caiano presented positive correlation only between root length and dry matter yield and E.I. (Table 4).
Baligar \& Barber (1979), in a study with several maize genotypes, observed that the genotype with the highest values for Vmax and $\mathrm{Km}$ presented the lowest $\mathrm{Cmin}$ and root length. The relationships between the Puptake kinetic parameters and the root dimension characters were not uniform for all evaluated genotypes, in accordance to the results found in the present experiment. Anghinoni et al. (1989) evaluated four maize genotypes ('Save 342', 'Agroceres 28', 'Pionner Px301' and 'Caçador') and concluded that 'Caçador' had favorable characteristics for $\mathrm{P}$ uptake because of its high value for Vmax and low value for Cmin. The hybrid Pionner Px301 had high Cmin indicating to be P-inefficient under low $\mathrm{P}$ conditions, and 'Save 342 ' presented a short root system with a restricted action range in the soil.

Theoretically, some authors have suggested that plants which are efficient for nutrient uptake should present high Vmax, which means having high uptake rates under high external concentrations, and low $\mathrm{Km}$ and $\mathrm{Cmin}$, which means to be able of taking up the nutrient from diluted solutions, such as the low fertile soil solutions (Schenk \& Barber, 1979b; 1980). Efficient plants should also have an extensive root system, a highly desirable character for selecting genotypes for P uptake efficiency (Nielsen \& Barber, 1978; Schenk \& Barber, 1979b).

Results obtained with 'Nitrodente' and 'BR 106' evidenced that these varieties are adapted to low external $\mathrm{P}$ conditions because of the characteristics of low Vmax and $\mathrm{Km}$ and larger root systems, with longer roots and higher 
Table 3 - Simple correlation coefficients (r) between P uptake kinetic parameters ${ }^{(1)}$ and the other evaluated variables ${ }^{(2)}$ in 24 day-old maize varieties grown in nutrient solution (pots with three plants; average of five replications).

\begin{tabular}{|c|c|c|c|c|c|c|c|c|c|c|c|c|c|c|c|c|}
\hline Variety & & SDM & RDM & TDM & $\mathrm{R} / \mathrm{S}$ & SPC & $\mathrm{RPC}$ & TPC & $S / R$ & UEI & RSA & RL & $\mathrm{RR}$ & Vmax & $\mathrm{Km}$ & $\mathrm{Cmin}$ \\
\hline \multirow[t]{3}{*}{ Caiano } & $V \max$ & 0.16 & 0.01 & 0.09 & -0.09 & -0.42 & -0.05 & -0.47 & 0.29 & 0.19 & 0.17 & 0.17 & -0.11 & - & -0.61 & 0.15 \\
\hline & $\mathrm{Km}$ & -0.64 & -0.69 & -0.67 & -0.66 & $0.91^{*}$ & -0.55 & 0.73 & 0.53 & -0.72 & $-0.88^{*}$ & $-0.88 *$ & 0.47 & -0.61 & - & -0.54 \\
\hline & $\mathrm{Cmin}$ & 0.08 & 0.24 & 0.16 & 0.34 & -0.22 & $0.95 * *$ & 0.16 & -0.69 & 0.02 & 0.67 & 0.51 & 0.21 & 0.15 & -0.54 & - \\
\hline \multirow[t]{3}{*}{ Carioca } & Vmax & 0.33 & -0.38 & 0.20 & -0.72 & $0.98 * *$ & -0.37 & $0.99 * *$ & 0.52 & -0.12 & -0.04 & -0.17 & 0.27 & - & -0.07 & -0.52 \\
\hline & $\mathrm{Km}$ & $-0.92 *$ & -0.73 & $-0.96 * *$ & 0.25 & -0.14 & 0.74 & -0.02 & -0.75 & $-0.95 * *$ & -0.71 & -0.77 & -0.02 & -0.07 & - & $0.88^{*}$ \\
\hline & $\mathrm{Cmin}$ & $-0.94 * *$ & -0.49 & $-0.92 *$ & 0.52 & -0.57 & $0.81+$ & -0.47 & $-0.90 *$ & $-0.78+$ & -0.56 & -0.60 & -0.06 & -0.52 & $0.88 *$ & - \\
\hline \multirow[t]{3}{*}{ Catetão } & Vmax & $-0.81+$ & $-0.99 * *$ & $-0.91 *$ & -0.71 & -0.21 & 0.47 & -0.20 & -0.41 & -0.60 & -0.65 & -0.76 & 0.02 & - & 0.63 & 0.51 \\
\hline & $\mathrm{Km}$ & $-0.84+$ & -0.65 & $-0.80+$ & -0.75 & 0.06 & -0.37 & 0.05 & 0.18 & -0.69 & -0.16 & -0.26 & 0.18 & 0.63 & - & 0.15 \\
\hline & $\mathrm{Cmin}$ & -0.17 & -0.49 & -0.29 & -0.69 & 0.08 & 0.58 & 0.10 & -0.20 & -0.29 & -0.75 & $-0.81+$ & -0.24 & 0.51 & 0.15 & - \\
\hline \multirow[t]{3}{*}{ S. Manhã NF } & Vmax & -0.71 & -0.66 & -0.70 & -0.47 & 0.29 & -0.23 & 0.22 & 0.24 & $-0.80+$ & -0.75 & -0.72 & -0.41 & - & 0.09 & -0.07 \\
\hline & $\mathrm{Km}$ & 0.09 & -0.18 & -0.02 & -0.34 & 0.34 & 0.16 & 0.33 & -0.10 & -0.15 & -0.16 & -0.25 & 0.75 & 0.09 & - & $0.86^{*}$ \\
\hline & $\mathrm{Cmin}$ & -0.15 & -0.42 & -0.26 & -0.62 & -0.06 & -0.28 & -0.11 & 0.28 & -0.29 & -0.35 & -0.43 & 0.74 & -0.07 & $0.86^{*}$ & - \\
\hline \multirow[t]{3}{*}{ Nitrodente } & Vmax & 0.35 & -0.10 & 0.20 & -0.57 & -0.65 & 0.58 & -0.63 & $-0.86^{*}$ & 0.64 & 0.36 & 0.35 & 0.33 & - & -0.54 & -0.33 \\
\hline & $\mathrm{Km}$ & $-0.92 *$ & -0.49 & $-0.81+$ & 0.22 & -0.21 & -0.68 & -0.24 & 0.31 & -0.45 & 0.45 & 0.47 & 0.50 & -0.54 & - & 0.76 \\
\hline & $\mathrm{Cmin}$ & -0.68 & -0.37 & -0.60 & 0.17 & -0.19 & -0.11 & -0.20 & 0.00 & -0.29 & 0.21 & 0.20 & 0.33 & -0.33 & 0.76 & - \\
\hline \multirow[t]{3}{*}{ BR 106} & Vmax & 0.57 & 0.06 & 0.32 & -0.18 & $-0.82+$ & -0.03 & $-0.82+$ & -0.43 & 0.71 & -0.52 & -0.45 & -0.66 & - & $-0.78+$ & -0.45 \\
\hline & $\mathrm{Km}$ & $-0.93^{*}$ & -0.61 & $-0.81+$ & -0.35 & 0.54 & -0.42 & 0.51 & 0.66 & $-0.94 * *$ & 0.04 & -0.07 & $0.87 *$ & -0.78 & - & 0.72 \\
\hline & $\mathrm{Cmin}$ & $-0.80+$ & $-0.82+$ & $-0.87 *$ & -0.70 & 0.14 & -0.69 & 0.10 & 0.65 & -0.73 & 0.27 & 0.18 & $0.87 *$ & -0.45 & 0.72 & - \\
\hline
\end{tabular}

${ }^{(1)} \mathrm{Vmax}=$ maximal $\mathrm{P}$ uptake rate (per unit of root dry matter); Km = Michaelis-Menten constant; Cmin = minimal external concentration; ${ }^{(2)} \mathrm{SDM}, \mathrm{RDM}, \mathrm{TDM}=$ shoot, root and total dry matter, respectively; R/S = root/shoot DM ratio; SPC, RPC, TPC = shoot, root and total $\mathrm{P}$ content, respectively; $\mathrm{S} / \mathrm{R}=$ shoot/root $\mathrm{P}$-content ratio; RSA, RL, RR = root surface area, length and radius, respectively; UEI = utilization efficiency index.

** Statistical significance at $P=0.01$; * Statistical significance at $P=0.05$; + Statistical significance at $P=0.10$ using 'Student t' test; other values statistically not significant.

surface area, in agreement to the results of Chapin III (1980, 1983) and Furlani (1988). These authors suggest that lower P uptake rates defined by lower Vmax values, might be a character of highly adapted plants to infertile soils. On the other hand, 'Sol da Manhã NF' is the variety with the smallest root length and surface area, presenting high values for Vmax and $\mathrm{Km}$, suggesting that it might be efficient in $\mathrm{P}$ acquisition under high external $\mathrm{P}$ conditions.

Total P contents of plants were not different among varieties in this experiment (Table 2), indicating that plants absorbed similar quantities of P. Thereafter, it was inferred from these results that 'Sol da Manhã NF' might have its shorter root system compensated by higher Vmax values, accelerating the P uptake kinetics, although this variety also presented a higher $\mathrm{Km}$ value, meaning lower afinity of the carrier binding sites for the P ions.

In previous studies (Machado et al., 2001) 'Sol da Manhã NF' presented lower total P contents, dry matter yields and $\mathrm{P}$ - efficiency indexes, in comparison to the other varieties. However, positive increasing responses were observed as $\mathrm{P}$ concentration in nutrient solution also increased (Machado et al., 2001), which evidences the hypothesis that this is a $\mathrm{P}$ uptake-efficient variety only when external $\mathrm{P}$ is not limitant.

In the field, as compared to the other varieties, 'Sol da Manhã NF' showed the highest P uptake efficiency index (total $\mathrm{P}$ in shoots and grains/total $\mathrm{P}$ applied as fertilizer), under adequate $\mathrm{P}$ level applied to the soil, as compared to other varieties (Machado et al., 2001). However, under low soil $\mathrm{P}$ conditions and without $\mathrm{P}$ fertilization, 'Sol da Manhã NF' had the lowest grain yield among the seven maize varieties (within them 'Caiano', 'Catetão' and 'Carioca'), although being responsive to $\mathrm{P}$ when applications to the soil increased from 8.7 to 140 $\mathrm{kg} \mathrm{ha}^{-1}$ (Machado et al., 1999).

'BR 106' and 'Nitrodente' had higher efficiency for P uptake, higher dry matter yield and higher P-utilization efficiency indexes under low and high external $\mathrm{P}$ availability, evidencing that these maize varieties are adapted to $\mathrm{P}$ deficient or $\mathrm{P}$ sufficient conditions. Under adequate external $\mathrm{P}$ in the field, BR 106' and 'Nitrodente' had lower P uptake efficiency indexes, but superior P utilization efficiency indexes, as compared to 'Sol da Manhã NF', evidencing their adaptability to $\mathrm{P}$ stress conditions (Machado et al., 2001). 
Table 4 - Simple correlation coefficients (r) between root morphological characters ${ }^{(1)}$ and the other evaluated variables ${ }^{(2)}$ in 24-day-old maize varieties grown in nutrient solution (pots with three plants; average of five replications).

\begin{tabular}{|c|c|c|c|c|c|c|c|c|c|c|}
\hline Variety & & SDM & RDM & TDM & $\mathrm{R} / \mathrm{S}$ & SPC & $\mathrm{RPC}$ & TPC & $\mathrm{S} / \mathrm{R}$ & UEI \\
\hline \multirow[t]{3}{*}{ Caiano } & RSA & 0.63 & $0.80+$ & 0.72 & $0.83+$ & $-0.84+$ & $0.79+$ & -0.56 & $-0.87 *$ & 0.70 \\
\hline & RL & $0.79+$ & $0.91 *$ & $0.86^{*}$ & $0.92 *$ & $-0.90 *$ & 0.64 & -0.68 & $-0.78+$ & $0.85+$ \\
\hline & $\mathrm{RR}$ & $0.96 * *$ & $-0.87 *$ & $-0.93^{*}$ & $-0.79+$ & 0.67 & 0.09 & 0.74 & 0.13 & $-0.93 *$ \\
\hline \multirow[t]{3}{*}{ Carioca } & RSA & 0.41 & 0.62 & 0.50 & 0.25 & -0.13 & -0.07 & -0.16 & 0.17 & 0.56 \\
\hline & RL & 0.50 & $0.90 *$ & 0.64 & 0.36 & -0.21 & -0.20 & -0.27 & 0.25 & 0.75 \\
\hline & $\mathrm{RR}$ & -0.09 & -0.44 & -0.18 & -0.20 & 0.16 & 0.23 & 0.22 & -0.12 & -0.28 \\
\hline \multirow[t]{3}{*}{ Catetão } & RSA & 0.52 & 0.65 & 0.58 & 0.48 & -0.39 & -0.62 & -0.42 & 0.00 & 0.67 \\
\hline & RL & 0.56 & 0.75 & 0.65 & 0.61 & -0.25 & -0.65 & -0.27 & 0.13 & 0.65 \\
\hline & RR & 0.16 & 0.01 & 0.11 & -0.21 & $-0.82+$ & -0.23 & $-0.83+$ & -0.50 & 0.52 \\
\hline \multirow[t]{3}{*}{ S. Manhã } & RSA & $0.96 * *$ & $0.97 * *$ & $0.98 * *$ & $0.89 *$ & 0.23 & 0.76 & 0.35 & -0.68 & $0.96 * *$ \\
\hline & $\mathrm{RL}$ & $0.93+$ & $0.97 * *$ & $0.96 * *$ & $0.90^{*}$ & 0.24 & 0.73 & 0.35 & 0.65 & $0.95 * *$ \\
\hline & $\mathrm{RR}$ & 0.39 & 0.19 & 0.31 & 0.02 & -0.19 & 0.26 & -0.12 & -0.37 & 0.32 \\
\hline \multirow[t]{3}{*}{ Nitrodente } & RSA & -0.43 & -0.24 & -0.38 & 0.03 & $-0.92 *$ & -0.18 & $-0.93 *$ & -0.55 & 0.44 \\
\hline & RL & -0.45 & -0.26 & -0.40 & 0.01 & $-0.91 *$ & -0.21 & $-0.93 *$ & -0.52 & 0.41 \\
\hline & $\mathrm{RR}$ & -0.44 & -0.21 & -0.38 & 0.09 & $-0.93^{*}$ & -0.11 & $-0.94 *$ & -0.58 & 0.46 \\
\hline \multirow[t]{3}{*}{ BR 106} & RSA & 0.05 & 0.32 & 0.20 & 0.36 & 0.30 & 0.31 & 0.33 & -0.10 & 0.02 \\
\hline & RL & 0.17 & 0.40 & 0.31 & 0.41 & 0.29 & 0.36 & 0.31 & -0.15 & 0.11 \\
\hline & $\mathrm{RR}$ & $-0.94 * *$ & -0.62 & -0.82 & -0.37 & 0.20 & -0.34 & 0.18 & 0.42 & -0.73 \\
\hline
\end{tabular}

${ }^{(1)} \mathrm{RSA}, \mathrm{RL}, \mathrm{RR}=$ root surface area, length and radius, respectively.

${ }^{(2)} \mathrm{SDM}, \mathrm{RDM}, \mathrm{TDM}=$ shoot, root and total dry matter, respectively; R/S = root/shoot DM ratio; SPC, RPC, TPC = shoot, root and total $\mathrm{P}$ content, respectively; $\mathrm{S} / \mathrm{R}=$ shoot/root $\mathrm{P}$-content ratio; $\mathrm{UEI}=$ utilization efficiency index.

** Statistical significance at $P=0.01$; *Statistical significance at $P=0.05$; + Statistical significance at $P=0.10$, by 'Student's t' test; other values, statistically not significant.

Less variation in $\mathrm{P}$ uptake kinetic parameters and related P-efficiency characters has been observed for genetically more stable and homogeneous genotypes like inbred lines and hybrids of maize and other species. Differences in these kinetic parameters (Vmax, Km and Cmin) among inbred lines and hybrids have been successfully correlated to the plant production characteristics, like plant $\mathrm{P}$ content, dry matter and grain yield and root dimension characters (Nielsen \& Barber, 1978; Nielsen \& Schjørring, 1983; Machado, 2000). The nutrient uptake kinetic parameters Vmax, $\mathrm{Km}$ and Cmin are important plant attributes to be considered when looking for efficient genoma, evaluating and selecting genotypes for higher efficiency of $\mathrm{P}$ uptake under low or high external $\mathrm{P}$ concentrations.

\section{CONCLUSIONS}

The maize varieties differed in relation to the $\mathrm{P}$ uptake kinetic parameters (Vmax and $\mathrm{Km}$ ) and to the root length and root / shoot dry matter ratio. 'BR 106' and 'Nitrodente', adapted varieties to low external $\mathrm{P}$ conditions, presented the lowest values for the kinetic parameters, which were good indicators of P-uptake efficiency of maize varieties in this experiment and were related to higher dry matter yield, higher P-utili- zation efficiency indexes and higher root lengths. The $\mathrm{P}$ uptake kinetic parameters Vmax, $\mathrm{Km}$ and Cmin 'per $s e$ ' allow the identification of genotypes adapted to low or high external $\mathrm{P}$ availability, but in order to be used as criteria for plant efficiency in $\mathrm{P}$ uptake and $\mathrm{P}$ utilization they need to be correlated to other P efficiency characters.

\section{ACKNOWLEDGEMENTS}

To FAPESP and CNPq for financial support.

\section{REFERENCES}

ALVES, V.M.C.; NOVAIS, R.F. de; OLIVEIRA, M.F.G. de; SANT' ANNA, R. Cinética e translocação de fósforo em híbridos de milho. Pesquisa Agropecuária Brasileira, v.33, p.1047-1052, 1998.

ANGHINONI, I.; VOLKART, C.R.; FATTORE, N.; ERNANI, P.R. Morfologia de raízes e cinética da absorção de nutrientes em diversas espécies e genótipos de plantas. Revista Brasileira de Ciência do Solo, v.13, p.355-361, 1989.

BALIGAR, V.C.; BARBER, S.A. Genotypic differences of corn for ion uptake. Agronomy Journal, v.71, p.870-873, 1979.

BATAGLIA, O.C.; FURLANI, A.M.C.; TEIXEIRA, J.P.F.; FURLANI, P.R.; GALLO, J.R. Métodos de análise química de plantas. Campinas: Instituto Agronômico, 1983. 48p. (Boletim, 78).

CHAPIN III, F.S. The mineral nutrition of wild plants. Annual Review of Ecology and Systematics, v.11, p.233-260, 1980.

CHAPIN III, F.S. Adaptation of selected trees and grasses to low avalability of phosphorus. Plant and Soil, v.72, p.283-287, 1983. 
CIARELLI, D.M.; FURLANI, A.M.C.; DECHEN, A.R.; LIMA, M. Genetic variation among maize genotypes for phosphorus-uptake and phosphorus-use efficiency in nutrient solution. Journal of Plant Nutrition, v.21, p.2219-2229, 1998.

FAGERIA, N.K.; BALIGAR, V.C. Response of legumes and cereals to phosphorus in solution culture. Journal of Plant Nutrition, v.12, p.1005-1019, 1989.

FÖHSE, D.; CLAASSEN, N.; JUNGK, A. Phosphorus efficiency of plants. I. External and internal $\mathrm{P}$ requirement and $\mathrm{P}$ uptake efficiency of different plant species. Plant and Soil, v.110, p.101-109, 1988.

FURLANI, A.M.C. Variações em parâmetros de cinética de absorção de fósforo de três linhagens de arroz. Revista Brasileira de Ciência do Solo, v.12, p.77-80, 1988.

FURLANI, A.M.C.; FURLANI, P.R. Composição e pH de soluções nutritivas para estudos fisiológicos e seleção de plantas em condições nutricionais adversas. Campinas: Instituto Agronômico, 1988. 34p. (Boletim, 121).

FURLANI, A.M.C.; CLARK, R.B.; MARANVILLE, J.W.; ROSS, W.M. Sorghum genotype differences in phosphorus uptake rate and distribution in plant parts. Journal of Plant Nutrition, v.7, p.1113-1126, 1984.

GILL, M.A.; SALIM, R.M.; ZIA, M.S. Maize growth and uptake of phosphate and copper at different ambient phosphate concentrations. Soil Science and Plant Nutrition, v.38, p.631-636, 1992.

JORGE, L.A. de C. Recomendações práticas para aquisição de imagens digitais analisadas através do SIARCS. São Carlos: EMBRAPA, Instrumentação Agropecuária, 1996. 44p. (Circular Técnica, 1)

JUNGK, A.; ASHER, C.J.; EDWARDS, D.G.; MEYER, D. Influence of phosphate status on phosphate uptake kinetics of maize (Zea mays) and soybean (Glycine max). Plant and Soil, v.124, p.175-182, 1990.

MACHADO, C.T. de T. Avaliação da eficiência de utilização de fósforo de variedades locais de milho (Zea mays L.) Itaguaí: UFRRJ, 1995. 131p. (Dissertação - Mestrado).

MACHADO, C.T. de T. Caracterização de genótipos de milho quanto a parâmetros morfológicos, fisiológicos e microbiológicos associados à eficiência de absorção e uso de fósforo. Seropédica: UFRRJ, 2000. 365p. (Tese - Doutorado).
MACHADO, C.T. de T.; FURLANI, A.M.C.; MACHADO, A.T. Índices de eficiência de variedades locais e melhoradas de milho ao fósforo. Bragantia, v.60, p.225-238, 2001.

MACHADO, C.T. de T.; GUERRA, J.G.M.; ALMEIDA, D.L. de; MACHADO, A.T. Variabilidade entre genótipos de milho para eficiência no uso de fósforo. Bragantia, v.58, p.109-124, 1999.

MARSCHNER, H. Mineral nutrition of higher plants. London: Academic Press, 1995. 889p.

MURPHY, J.; RILEY, J.P. A modified single solution method for determination of phosphate in natural waters. Analytica Chimica Acta, v.27, p.31-36, 1962.

NIELSEN, N.E.; BARBER, S.A. Differences among genotypes of corn in the kinetics of P uptake. Agronomy Journal, v.70, p.695-698, 1978.

NIELSEN, N.E.; SCHJØRRING, J.K. Efficiency and kinetics of phosphorus uptake from soil by various barley genotypes. Plant and Soil, v.72, p.225-230, 1983.

ROSSIELLO, R.O.P.; ARAÚJO, A.P.; MANZATTO, C.V.; FERNANDES, M.S. Comparação dos métodos fotoelétrico e da interseção na determinação de área, comprimento e raio médio radicular. Pesquisa Agropecuária Brasileira, v.30, p.633-638, 1995.

RUIZ, H.A. Estimativa dos parâmetros cinéticos Km e Vmax por uma aproximação gráfico-matemática. Revista Ceres, v.32, p.79-84, 1985.

SCHENK, M.K.; BARBER, S.A. Root characteristics of corn genotypes as related to P uptake. Agronomy Journal, v.71, p.921-924, 1979a.

SCHENK, M.K.; BARBER, S.A. Root characteristics of corn genotypes as related to P uptake. Agronomy Journal, v.71, p.921-924, 1979b.

SCHENK, M.K. ; BARBER, S.A. Potassium and phosphorus uptake by corn genotypes grown in the field as influenced by root characteristics. Plant and Soil, v.54, p.65-76, 1980.

SIDDIQI, M.Y.; GLASS, A.D.M. Utilization Index: A modified approach to the estimations and comparison of nutrient utilization efficiency in plants. Journal of Plant Nutrition, v.4, p.289-302, 1981.

Received October 11, 2002

Accepted October 23, 2003 